\title{
Effect of Protein Supplements on Nutrient Utilization and Production of Lactating Gir Cows
}

\author{
Lekhu Kumar ${ }^{1 *}$, R.P. Jat ${ }^{2}$, Subhash Yadav $^{1}$ and Maya Jat ${ }^{1}$ \\ ${ }^{1}$ Department of Livestock Production Management, SKNAU, Jobner, Rajasthan, INDIA \\ ${ }^{2}$ Professor, Department of Livestock Production Management and Dean, COA, Jhilai-Niwai, Tonk, Rajasthan, INDIA \\ "Corresponding author: L Kumar; E-mail: lekhuchangil31121995@gmail.com
}

Received: 21 June, $2021 \quad$ Revised: 17 July, $2021 \quad$ Accepted: 19 July, 2021

\begin{abstract}
A study was conducted on 16 lactating Gir cows, which were divided into four groups on the basis of body weight and average milk yield/day at Dairy farm (LPM Deptt.) S.K.N. College of agriculture, Jobner (Rajasthan) and subjected to four dietary treatments i.e. Wheat straw ad-lib.+ Green Lucerne $(5 \mathrm{~kg})+$ Concentrate $\left(\mathrm{T}_{1}\right), \mathrm{T}_{1}+$ Urea $75 \mathrm{~g} / \mathrm{cow}\left(\mathrm{T}_{2}\right), \mathrm{T}_{1}+$ Mustard oil cake $614 \mathrm{~g} /$ cow $\left(\mathrm{T}_{3}\right)$ and $\mathrm{T}_{1}+$ Guar meal $505 \mathrm{~g} / \mathrm{cow}\left(\mathrm{T}_{4}\right)$. The studied for their nutrients utilization of protein supplements and milk yield of Gir cows. Average daily intake of CP and DCP in kg/100 kg body weight was significantly higher $(\mathrm{P}<0.05)$ in $\mathrm{T}_{4}$ compared to other groups Average daily TDNI kg/100kg body weight was significantly higher $(\mathrm{P}<0.05)$ in $\mathrm{T}_{4}(1.56)$ compared to $\mathrm{T}_{3}(1.41), \mathrm{T}_{2}(1.32)$ and $\mathrm{T}_{1}(1.24)$ groups. The nutrient utilization as DM, CP, EE and NFE was significantly $(\mathrm{P}<0.05)$ higher in $\mathrm{T}_{4}$ compared to $\mathrm{T}_{3}, \mathrm{~T}_{2}$ and $\mathrm{T}_{1}$ groups Crude fibre was significantly $(\mathrm{P}<0.05)$ higher in $\mathrm{T}_{3}$ compared to $\mathrm{T}_{4}, \mathrm{~T}_{2}$ and $\mathrm{T}_{1}$ groups. Average daily milk production (litre/cow) was significantly $(\mathrm{P}<0.05)$ higher in $\mathrm{T}_{4}(7.85)$ than $\mathrm{T}_{3}(7.13), \mathrm{T}_{2}(7.05)$ and $\mathrm{T}_{1}(6.67)$. It can be inferred from this experiment that feeding of concentrate mixture on Wheat straw diet with Guar meal supplement increased the milk production.
\end{abstract}

\section{HIGHLIGHTS}

(0 We studied on effect of protein supplements on Nutrient Utilization and Production of Lactating Gir Cows

( F Feeding of Guar meal increased the milk production and digestibility as compared to Urea and Mustard oil cake in Gir cows.

(0 Guar meal may be increased palatability and utility of poor quality roughage.

Keywords: Gir cows, Milk yield, Nutrient utilization, Protein Supplement, Total Digestive Nutrients

Livestock is an integral part of agriculture and plays an important role in contributing to national economy. Total Milk production in the India was 187.7 million tonnes during 2019. India is the world's largest milk producer, with 21 per cent global production. The per capita availability of milk in India was $394 \mathrm{~g}$ per day in 2018-19 (GOI, 2018-2019). Rajasthan is ranked $2^{\text {nd }}$ in India and produces 23.6 million tonnes of milk every year. The per capita availability of milk in Rajasthan was $870 \mathrm{~g}$ (GOI, 2018-2019). Total cattle population in the India was 192.49 M (GOI, 2019) and total indigenous cattle population in India was 142.11M (GOI, 2019). Total cattle population in Rajasthan was 13.9 M (GOI, 2019). Gir is a most important milch cattle breed of India. The distribution of this breed is Gir hills and forest of Kathiawar and Amreli districts of Gujarat and also in some parts of Maharashtra and Rajasthan. The body of Gir animals is well proportioned, the head is moderately long but massive in appearance with prominent bony forehead straight and leveled back are the most the marking characters of the breed and body colour is red to white, Udder is well developed and round in Gir cattle. Cattle of this breed are good milk yielders in

How to cite this article: Kumar, L., Jat, R.P., Yadav, S. and Jat, M. (2021) Effect of Protein Supplements on Nutrient Utilization and Production of Lactating Gir Cows. J. Anim. Res., 11(04): 627-635.

Source of Support: None; Conflict of Interest: None क) क्ष 
the Indigenous cattle. Total lactation milk yield averaged 2063 litres in an average lactation period of 326 days. Milk yield per day was 4.98 litres. Average fat percentage in the milk ranged between $4.69 \pm 0.04$ and $4.97 \pm 0.02$ (Gaur et al., 2003). Nutrition plays crucial role in growth, reproduction and production of animals but the biomass resources are very limited and there is shortage of feed and fodder. There is a serious shortage of conventional feed resources. Hence, it is necessary to look for protein rich, nonconventional feed resources. In India there is shortage of 22.5 per cent dry fodder, 62.7 per cent green fodder (IGFRI, 2010) and 34 per cent concentrate to meet the requirement of vast bovine population. Urea is nonprotein nitrogen compound. As an NPN-source urea can replace part of the dietary protein in the ruminant diet. Urea contains about 46 per cent nitrogen and protein contains 16 per cent nitrogen. The crude protein equivalent value of urea is about 287 per cent crude protein. Urea when used for treatment of straw boost the nutritional quality of straw in terms of increased nitrogen content, enhanced the palatability and digestibility.

The composition of mustard cake (MC) varies with the variety, growing conditions and processing methods. The crude protein content varies from 33-40 per cent in mustard cake. Mustard cake contains 21 per cent carbohydrate, 8.5 per cent crude fiber and 8 per cent ash (Sehwag et al., 2015). Mustard cakes have D.C.P. and T.D.N. values 27 per cent and 74 per cent respectively. Guar meal is considered as a potential unconventional feed resource for livestock. Guar Meal used in concentrate rations for lactating dairy cows. Processed meal can be used as the sole protein component of cattle diets. Guar meal contains 38-50 per cent protein depending on the type of fraction (Salehpour et al., 2012). It is extensively used as emulsifier, thickener and stabilizer in food and oil industries. Guar meal have about 65 per cent T.D.N.. Being a rich source of proteins, nutrients and fibres with high digestibility, it is being used as feed after processing for animals. It is having upto 50 per cent of protein with a high digesting content, which improves digestive system of cows. As it is very high in protein it gives, extra fat in its milk and also increase the quantity of milk. In view of lack of protein resources, appropriate treatment on cakes may be one of the strategies to provide the collision us to efficiency of utilization of nutrients for development and milk. Mustard cake and Guar meal is relatively very rich in energy and protein contents than other feed ingredients. The supplementation of forages by oil cakes could be a potential way to improve the nutritional quality of lowquality feeds (Khandakar et al., 2011).

\section{MATERIALS AND METHODS}

The experiment was carried out at Dairy farm, Department of Livestock Production Management, S.K.N. College of Agriculture, Jobner (Jaipur). Sixteen lactating Gir cows in mid stage of lactation were selected for the experiment. They were randomly divided into four groups of four in each group on basis of nearness in their production and body weight of cows and four dietary treatments were formulated i.e. Wheat straw ad lib. $+5.0 \mathrm{~kg}$ Lucerne + Concentrate palleted feed $\left(\mathrm{T}_{1}\right), \mathrm{T}_{1}+$ Urea @75 g per cow per day $\left(\mathrm{T}_{2}\right), \mathrm{T}_{1}+$ Mustard cake @614 g per cow per day $\left(\mathrm{T}_{3}\right)$ and $\mathrm{T}_{1}+$ Guar meal @ 505 g per cow per day $\left(\mathrm{T}_{4}\right)$ and the studied for their feed intake and water intake in Gir cows. A system of housing is more or less synonymous to the system of management of dairy cattle. Similar housing and managemental facilities were provided to all the groups.

\section{Feeds and feeding of animals}

Animal were stall fed individually ad libitum of dry fodder and weighed quantities of rations were offered twice in a day. The concentrate used palleted prepared feed from RCDF which contain 18 per cent crude protein and 75 per cent DCP and Lucerne (Medicago sativa) green fodder and Wheat straw dry fodder were used as roughages. The animals were fed in the morning and evening as per their requirement the feeding schedule of gir cows is given table 1 .

\section{Parameters studied and observation taken}

\section{Collection of dung}

The animal were housed in closed barn and fed twice a day. The faeces were collected quantitatively once a day before the morning meal. Total dung voided by each Gir cows during twenty four hours was collected and weighed. Adequate care was taken to avoid mixing of feces with urine. A $100 \mathrm{gm}$ representative sample of $1 / 100^{\text {th }}$ part of 
Table 1: Feeding schedule of Gir cows

\begin{tabular}{lll}
\hline Sl. No. & Feed and Fodders & Quantity of feed and fodders \\
\hline 1 & Concentrate pelleted feed & Maintenance ration production ratio $2 \mathrm{~kg} /$ animal and production ratio given to animal \\
& & $1 \mathrm{~kg} / 2.5$ liter milk yield \\
2 & Protein Supplements & Urea $75 \mathrm{~g}$, Mustard cake $614 \mathrm{~g}$ and Guar meal $505 \mathrm{~g}$ per cow treatment wise. \\
3 & Lucerne green & $5.0 \mathrm{~kg}$ per cow \\
4 & Dry fodder (Wheat straw) & Ad libtum \\
\hline
\end{tabular}

total feces of each animal was weighed in a silk dish daily and were kept in hot air oven at $105^{\circ} \mathrm{C}$ temperature for overnight for the determination of dry matter.

\section{Chemical analysis of feeds, fodder, refusal and feaces}

The chemical and in-vitro analysis was done in the Dry matter content of dry fodder (Wheat straw), concentrate (pelleted feed) and feaces (cow dung) were determined. The samples of feed, fodder and feaces, residue left over were analyzed for proximate principles (AOAC, 2000). To formulate the ration values were taken from actual analysis of the sample at laboratory of Goat RKVY project and Nutrition laboratory of CSWRI, Avikanager. The methodology used for analysis was as follows:-

\section{Determination of Dry matter}

The representative samples were analyzed for dry matter (DM), total ash (TA), crude protein (CP), ether extract (EE) and crude fiber (CF). The DM was determined by dry samples at temperature $105^{\circ} \mathrm{C}$ in a hot air oven for 24 hours. Dry the moisture cup in an oven at $100^{\circ} \mathrm{C}$, cool it in a desiccators and record its weight. Take about $10 \mathrm{~g}$ of the material in the moisture cup and weigh out to calculate actual amount of material taken.

Moisture $(\%)=$

$\underline{\text { Initial wt. of moisture cup }+ \text { Sample }- \text { Final wt. After drying }} \times 100$ Wt. of the sample

Dry matter $=100-$ Moisture $(\%)$

\section{Crude protein estimation}

Crude protein in various samples of feed and faeces was analyzed using semi auto analyzer Kelplus nitrogen estimation system (Pelican Equip). For this take $0.5 \mathrm{gm}$ of sample and transferred it to the digestion tube. Add 10-15 ml of concentrated Sulphuric acid and 5-7 gm of digestion activator to the sample. Then the digestion tube is loaded into digester and the digestion block is heated by maintaining the block temperature between $360^{\circ} \mathrm{C}-410^{\circ} \mathrm{C}$. The sample turns colorless or light green color at the end of digestion. After digestion, the measured quantity of aliquot was distilled in automatic distillation system by adding 40 per cent $\mathrm{NaOH}$ by auto mode until brown color develops. Then the digested sample was heated by passing steam and the ammonia liberated was trapped into 4 per cent boric acid and mixed indicator $(0.3 \mathrm{~g}$ of 67 bromocresol green and $0.2 \mathrm{~g}$ methyl red in $400 \mathrm{ml}$ of 90 per cent ethanol). The distillate was titrated against $0.1 \mathrm{~N} \mathrm{H}_{2} \mathrm{SO}_{4}$. The quantity of nitrogen was estimated, on the basis of fact that $1.0 \mathrm{ml}$ of standard $0.1 \mathrm{~N} \mathrm{H}_{2} \mathrm{SO}_{4}$ is equivalent to $0.0014 \mathrm{~g}$ nitrogen. The CP content in the sample was determined as a multiple factor 6.25 , following the equation-

$$
\begin{aligned}
& \text { Nitrogen }(\%)= \\
& \frac{10-15 \mathrm{ml} \text { of N} / 10 \text { sulphuric acid } \times 0.0014 \times \mathrm{D}}{\text { Sample weight }(\mathrm{g}) \times \mathrm{A}} \times 100
\end{aligned}
$$

Where,

$0.0014=$ Standard factor

$\mathrm{D}=$ Dilution factor

$\mathrm{A}=$ Aliquot taken

Per cent $\mathrm{CP}=$ Per cent $\mathrm{N} \times 6.25$

\section{Total fat/ Ether extract}

Estimation of ether extract in feed and faeces was done with the help of Soxhlet's apparatus. For this $2 \mathrm{~g}$ of oven dried powdered sample was taken in a thimble. This 
was placed in the extraction tube of Soxhlet's apparatus. The extraction tube was connected above with the water condenser and below with oil flasks through standard joints. Extraction was carried out for six hours with petroleum ether (AR) of boiling point 40 to $60^{\circ} \mathrm{C}$, at the rate of eight extractions per hour. At the end of each extraction the flask was then disconnected, it's contents were dried in an oven and the flask along with fatty residue was weighed after cooling in a desiccators. The difference in the two weights denoted the amount of ether extract in the sample. The results were expressed on percentage basis. The ether extract was calculated as follows:

$$
\text { Ether extract }(\%)=\frac{100\left(W_{1}-W_{2}\right)}{W}
$$

Where,

$W_{1}=$ Weight $(\mathrm{g})$ of oil flask with the dried ether extract

$W_{2}=$ Weight $(\mathrm{g})$ of oil flask

$W=$ Weight $(\mathrm{g})$ of dried material taken

\section{Crude fiber}

Transfer the weighed fat free samples into oven dried crucibles. Place the crucible into the metal adopter of fiber plus hot extraction unit and Acid wash with pour $150 \mathrm{ml}$ of $1.25 \mathrm{H}_{2} \mathrm{SO}_{4}$ at $500^{\circ} \mathrm{C}$ for $40 \mathrm{~min}$. After $40 \mathrm{~min}$. boiling, drain the acid and wash the samples twice or thrice with distilled water. There after Alkali wash with pour $150 \mathrm{ml}$ of $1.25 \mathrm{NaOH}$ at $500^{\circ} \mathrm{C}$ for $40 \mathrm{~min}$. After $40 \mathrm{~min}$. boiling, drain the acid and wash the samples twice or thrice with distilled water. After alkali wash take out crucibles and dry them in hot air oven until the crucibles are free from moisture. Weight the crucibles and place all crucibles in ignited the muffle furnace at $550^{\circ} \mathrm{C}$ for four hours ashing. Weight crucibles after ashing record the reading.

$$
\text { Crude fiber content }(\%)=\frac{A-B}{C} \times 100
$$

$A=$ weight of crucible with dry residue $(\mathrm{g}) ; B=$ weight of crucible with ash $(\mathrm{g}) ; C=$ weight of sample $(\mathrm{g})$

\section{Total ash}

$5 \mathrm{~g}$ dried sample was placed in the pre-weighed silica crucible, smoked and then total ash was determined by ashing at a temperature $550^{\circ} \mathrm{C}$ in muffle furnace for 6 hours (AOAC, 2000) and expressed as percent of the dried sample.

$$
\text { Ash }(\mathrm{g} / 100 \mathrm{~g})=\frac{\text { Weight of Ash }}{\text { Weight of sample }} \times 100
$$

\section{Calculation of Nitrogen-Free Extract (NFE)}

$$
\text { NFE }(\%)=100-(\mathrm{CP} \%+\mathrm{CF} \%+\mathrm{EE} \%+\text { Total ash })
$$

Where,

$$
\begin{aligned}
& \mathrm{CP}=\text { Crude protein } \\
& \mathrm{CF}=\text { Crude fibre } \\
& \mathrm{EE}=\text { Ether extract }
\end{aligned}
$$

\section{Total Digestible Nutrients (TDN)}

$$
\mathrm{TDN}=\mathrm{DCP}+\mathrm{DCF}+\mathrm{DNFE}+\mathrm{DEE} \times 2.25
$$

Where,

$$
\begin{aligned}
& \mathrm{TDN}=\text { Total digestible nutrients }(\mathrm{kg}) \\
& \mathrm{DCP}=\text { Digestible crude protein } \\
& \mathrm{DCF}=\text { Digestible crude fibre } \\
& \mathrm{DNFE}=\text { Digestible nitrogen free extra } \\
& \mathrm{DEE}=\text { Digestible ether extract }
\end{aligned}
$$

\section{Milk yield}

All cows were cleaned and washed before each milking throughout the experiment routine practices of farm. The record of daily milk yield of each cow were maintained throughout the experiment peroid of 90 days. The milk yield was be recorded daily in the morning and evening to nearest $50 \mathrm{gm}$ with the help of $100 \mathrm{~kg}$ electronic weighing machine during the experiment. Milking of individual cows was done by hand and machine milking.

\section{Statistical analysis of data}

The data obtained was processed to analysis of variance as per standard method (Snedecor and Cochran, 1994). Different statistical tools such as mean, standard deviation (SD), standard error (SE) were worked out to compare the group. 


\section{RESULTS AND DISCUSSION}

The data collected during the experimental trial were subjected to standard methods of statistical analysis and presented in this chapter in the form of tables, graphs along with the implications of the results to the effect of protein supplements on nutrients utilization and production of lactating Gir cows under following heads:-

\section{Proximate composition of feed and fodders}

The Chemical composition of different feed and fodders ingredients on laboratory is given in Table 2 .

\section{Crude protein and digestible crude protein intake}

The average crude protein intakes (CPI) have been given in Table 3. The daily CP intake in $\mathrm{T}_{1}, \mathrm{~T}_{2}, \mathrm{~T}_{3}$ and $\mathrm{T}_{4}$ groups cows were $1.26 \pm 0.04,1.21 \pm 0.06,1.34 \pm 0.04$ and $1.36 \pm 0.03$ g, respectively. The mean CPI $100 \mathrm{~kg}$ body weight was $0.292 \pm 0.02,0.278 \pm 0.07,0.308 \pm 0.02$ and $0.312 \pm 0.001 \mathrm{~kg}$, respectively. The $\mathrm{CP}$ intake in the treatment $\mathrm{T}_{4}$ was more $(\mathrm{P}<0.05)$ as compared to $\mathrm{T}_{3}, \mathrm{~T}_{2}$ and $\mathrm{T}_{1}$ groups. The average daily DCP intake (DCPI) was $0.620 \pm 0.085,0.685 \pm 0.115$, $0.745 \pm 0.072$ and $0.798 \pm 0.075 \mathrm{~g}$, respectively. The mean
DCPI $/ 100 \mathrm{~kg}$ body weight was $0.143 \pm 0.041,0.157 \pm 0.055$, $0.171 \pm 0.035$ and $0.183 \pm 0.036 \mathrm{~kg}$, respectively.

The DCP intake in the treatment $\mathrm{T}_{4}$ was higher than $\mathrm{T}_{3}, \mathrm{~T}_{2}$ and $\mathrm{T}_{1}(\mathrm{P}<0.05)$. The higher crude protein and digestible crude protein intake in treatment $\mathrm{T}_{4}$ group might be attributed to higher dry matter intake, which was due to better utility of nutrients through feed additive as Guar meal conditions. Crude protein intake by the animals was sufficient to meet the body requirements. Prasad et al. (1998) Found that the rate of CP digestion decreases with increasing the proportion of guar meal. The results are in agreement with the findings of Imaizumi et al. (2010). Wala et al. (2016) found that increasing level of Guar meal in buffalo's diet also increasing DCP.

\section{Total digestible nutrients intake}

The average total digestible nutrients intake (TDNI) has been given in Table 3 . The daily consumption of TDN by cows was $5.38 \pm 0.177,5.74 \pm 0.175,6.13 \pm 0.219$ and $6.79 \pm 0.308 \mathrm{~kg}$ in treatments $\mathrm{T}_{1}, \mathrm{~T}_{2}, \mathrm{~T}_{3}$ and $\mathrm{T}_{4}$ respectively. The feed supplements had significant $(\mathrm{P}<0.05)$ influence on TDN intake by Gir cows. The average daily TDN intake was more $(\mathrm{P}<0.05)$ in $\mathrm{T}_{4}$ as compared to $\mathrm{T}_{3}, \mathrm{~T}_{2}$ and $\mathrm{T}_{1}$

Table 2: Chemical compositions (\%) of feed and fodder (DM basis)

\begin{tabular}{|c|c|c|c|c|c|c|c|}
\hline SI. No. & Feed ingredients & DM & $\mathbf{C P}$ & $\mathbf{E E}$ & CF & NFE & ASH \\
\hline 1 & Concentrate mix. & 90.30 & 19.26 & 3.60 & 6.22 & 60.42 & 10.5 \\
\hline 2 & Wheat Straw & 91.27 & 4.10 & 1.30 & 34.20 & 49.20 & 11.20 \\
\hline 3 & Green Lucerne & 24.50 & 18.30 & 2.05 & 19.80 & 46.95 & 12.90 \\
\hline 4 & Mustard cake & 90.70 & 35.00 & 10.25 & 9.87 & 35.28 & 9.60 \\
\hline 5 & Guar meal & 93.40 & 42.5 & 4.75 & 9.12 & 37.92 & 5.71 \\
\hline 6 & Urea & - & 287.5 & - & - & - & - \\
\hline
\end{tabular}

Table 3: Average daily intake of crude protein, DCP and TDN in $(\mathrm{kg})$ in cows under different treatments during winter season

\begin{tabular}{lllll}
\hline Parameters & $\mathbf{T}_{\mathbf{1}}$ & $\mathbf{T}_{2}$ & $\mathbf{T}_{\mathbf{3}}$ & $\mathbf{T}_{\mathbf{4}}$ \\
\hline Crude protein intake (CPI) & $1.26^{\mathrm{c}} \pm 0.04$ & $1.21^{\mathrm{d}} \pm 0.06$ & $1.34^{\mathrm{b}} \pm 0.04$ & $1.36^{\mathrm{a}} \pm 0.03$ \\
CPI/100 kg BW & $0.290^{\mathrm{c}} \pm 0.02$ & $0.278^{\mathrm{d}} \pm 0.07$ & $0.308^{\mathrm{b}} \pm 0.02$ & $0.312^{\mathrm{a}} \pm 0.01$ \\
DCP intake & $0.620^{\mathrm{d}} \pm 0.085$ & $0.685^{\mathrm{c}} \pm 0.115$ & $0.745^{\mathrm{b}} \pm 0.072$ & $0.798^{\mathrm{a}} \pm 0.075$ \\
DCP intake/100 kg BW & $0.143^{\mathrm{d}} \pm 0.041$ & $0.157^{\mathrm{c}} \pm 0.055$ & $0.171^{\mathrm{b}} \pm 0.035$ & $0.183^{\mathrm{a}} \pm 0.036$ \\
Daily TDN intake & $5.38 \pm 0.177$ & $5.74 \pm 0.175$ & $6.13 \pm 0.219$ & $6.79 \pm 0.308$ \\
TDN intake/100 kg BW & $1.24 \pm 0.085$ & $1.32 \pm 0.084$ & $1.41 \pm 0.105$ & $1.56 \pm 0.148$ \\
\hline
\end{tabular}

Means having different superscripts differ significantly $(\mathrm{P}<0.05)$. 
groups. When TDN intake was calculated on $100 \mathrm{~kg}$ body weight basis it was $1.24 \pm 0.085,1.32 \pm 0.084,1.41 \pm 0.105$ and $1.56 \pm 0.148 \mathrm{~kg}$ in $\mathrm{T}_{1}, \mathrm{~T}_{2}, \mathrm{~T}_{3}$ and $\mathrm{T}_{4}$ cows, respectively.

The TDN intake was higher in $\mathrm{T}_{4}$ group than other three groups $T_{3}, T_{1}$ and $T_{2}$. Improved nutrient utilization with higher feed intake resulted higher TDNI in Guar meal supplemented group. The higher DCP and TDNI in $\mathrm{T}_{4}$ as compared to $\mathrm{T}_{3}, \mathrm{~T}_{2}$ and $\mathrm{T}_{1}$ group cows might be attributed to higher DMI. The results are in agreement with the findings of Rekhate, et al. (2008). Wala et al. (2016) indicated that increasing TDN intake with increasing level of Guar meal.

\section{Digestibility co-efficient of feed nutrients}

Apparent digestibility for sake of brevity will here after be called digestibility. The average digestibility co-efficient of various nutrients in different experimental groups are presented in Table 4, which indicated that the digestibility coefficient of all nutrients. The nutrient digestibility was significantly $(\mathrm{P}<0.05)$ higher in $\mathrm{T}_{4}$ group.

The average digestibility of Dry Matter (DM) in $\mathrm{T}_{1}, \mathrm{~T}_{2}, \mathrm{~T}_{3}$ and $\mathrm{T}_{4}$ was $62.54 \pm 0.150,62.89 \pm 0.190,64.78 \pm 0.201$ and $65.62 \pm 0.216$ per cent, respectively. The digestibility of Crude protein (CP) in $\mathrm{T}_{1}, \mathrm{~T}_{2}, \mathrm{~T}_{3}$ and $\mathrm{T}_{4}$ was $52.47 \pm 0.105$, $58.12 \pm 0.110,61.08 \pm 0.167$ and $62.11 \pm 0.145$ per cent, respectively. Which was higher $(\mathrm{P}<0.05)$ in $\mathrm{T}_{4}$ than $\mathrm{T}_{3}, \mathrm{~T}_{2}$ and $\mathrm{T} 1$ groups. The digestibility of Ether extract $(\mathrm{EE})$ in $\mathrm{T}_{1}$, $\mathrm{T}_{2}, \mathrm{~T}_{3}$ and $\mathrm{T}_{4}$ was $55.55 \pm 0.278,58.45 \pm 0.154,61.06 \pm 0.245$ and $63.09 \pm 0.115$ per cent, respectively. The digestibility of Crude fibre (CF) in $\mathrm{T}_{1}, \mathrm{~T}_{2}, \mathrm{~T}_{3}$ and $\mathrm{T}_{4}$ was $61.88 \pm 0.450$, $60.24 \pm 0.140,62.19 \pm 0.354$ and $61.70 \pm 0.102$ per cent, respectively. The digestibility of Nitrogen free extracts (NFE) in $\mathrm{T}_{1}, \mathrm{~T}_{2}, \mathrm{~T}_{3}$ and $\mathrm{T}_{4}$ was $68.12 \pm 0.107,68.84 \pm 0.169$, $71.05 \pm 0.151$ and $72.84 \pm 0.121$ per cent, respectively.
The digestibility co-efficient of DM was higher $(\mathrm{P}<0.05)$ in $\mathrm{T}_{4}$ than $\mathrm{T}_{3}, \mathrm{~T}_{2}$ and $\mathrm{T}_{1}$ groups. Felisberto et al. (2011) reported that DM digestibility was significantly higher by protein supplements. Similar trend were reported by Sharma et al. (2012). Crude protein was higher $(\mathrm{P}<0.05)$ in $T_{4}$ than $T_{3}, T_{2}$ and $T_{1}$ groups. Broderick (2003) agreed with adding protein supplements in animal diets to increase CP. Garg et al. (2003) agreed with crude protein intake increase by supplementing of protein sources in animal diet. Batista et al. (2016) founded that CP digestibility was increased with protein supplements. Similar result reported by Rufino et al. (2016). The digestibility coefficient of EE was higher in $\mathrm{T}_{4}$ group than $\mathrm{T}_{3}, \mathrm{~T}_{2}$ and $\mathrm{T}_{1}$ groups. Jongwe et al. (2014) reported that protein supplements also increase digestive EE. The digestibility co-efficient of CF was not also significant differ between the treatments. Jelantik et al. (2010) reported that crude fibre was significantly improved by supplementation of protein source.

The digestibility of nitrogen free extract was higher $(\mathrm{P}<0.05)$ in $\mathrm{T}_{4}$ than $\mathrm{T}_{3}, \mathrm{~T}_{2}$ and $\mathrm{T}_{1}$ groups animals. Apparent digestibility of DM, CP, and NFE were significantly $(\mathrm{P}<0.05)$ higher in $\mathrm{T}_{4}$, as compared to $\mathrm{T}_{3}, \mathrm{~T}_{2}$ and $\mathrm{T}_{1}$ groups due to higher DMI and VWI which was more palatable with the protein supplements. These results are in close agreement to the findings of Prasad et al. (1998). Khandakar et al. (2011) significant $(\mathrm{P}<0.01)$ increase is digestibility value are obtained for DM, OM, CP in rumen. The DM, $\mathrm{OM}, \mathrm{CP}$, digestibility were higher is treated than untreated rice straw. However these were no different between urea \& urea-calcium. Etaman et al. (2014) who reported that the increasing Guar korma level in experimental ration tended significantly $(\mathrm{P}<0.01)$ increase $\mathrm{DM}, \mathrm{OM}, \mathrm{CP}, \mathrm{EE}$ \& CF digestibility. Wala et al. (2016) agreed the values of all parameter were slightly increase with increasing the

Table 4: Average digestibility coefficient of nutrient under different treatments during winter season

\begin{tabular}{lllll}
\hline Nutrients & $\mathbf{T}_{1}$ & $\mathbf{T}_{2}$ & $\mathbf{T}_{3}$ & $\mathbf{T}_{4}$ \\
\hline DM & $62.54^{\mathrm{d}} \pm 0.150$ & $62.89^{\mathrm{c}} \pm 0.190$ & $64.78^{\mathrm{b}} \pm 0.201$ & $65.62^{\mathrm{a}} \pm 0.216$ \\
CP & $52.47^{\mathrm{d}} \pm 0.105$ & $58.12^{\mathrm{c}} \pm 0.110$ & $61.08^{\mathrm{b}} \pm 0.167$ & $62.11^{\mathrm{a}} \pm 0.145$ \\
EE & $55.55^{\mathrm{d}} \pm 0.278$ & $58.45^{\mathrm{c}} \pm 0.154$ & $61.06^{\mathrm{b}} \pm 0.245$ & $63.09^{\mathrm{a}} \pm 0.115$ \\
CF & $61.88^{\mathrm{b}} \pm 0.450$ & $60.24^{\mathrm{d}} \pm 0.140$ & $62.19^{\mathrm{a}} \pm 0.354$ & $61.70^{\mathrm{c}} \pm 0.102$ \\
NFE & $68.12^{\mathrm{d}} \pm 0.107$ & $68.84^{\mathrm{c}} \pm 0.169$ & $71.05^{\mathrm{b}} \pm 0.151$ & $72.84^{\mathrm{a}} \pm 0.121$ \\
\hline
\end{tabular}

Means having different superscripts differ significantly $(\mathrm{P}<0.05)$. 
replacement level of Guar meal concentrate in concentrate feed mixture.

\section{Milk yield}

The mean value of milk production data recorded under different treatments is presented in Table 5 and Fig. 1. The average milk production in morning was $3.63 \pm 0.29$, $3.85 \pm 0.09,3.85 \pm 0.09$ and $4.33 \pm 0.15$ litre/day in $\mathrm{T}_{1}, \mathrm{~T}_{2}$, $\mathrm{T}_{3}$ and $\mathrm{T}_{4}$, respectively. The average milk production in evening was $3.04 \pm 0.20,3.20 \pm 0.07,3.73 \pm 0.17$ and $3.52 \pm 0.10$ litre/day in $\mathrm{T}_{1}, \mathrm{~T}_{2}, \mathrm{~T}_{3}$ and $\mathrm{T}_{4}$, respectively. The total milk production in $\mathrm{T}_{1}, \mathrm{~T}_{2}, \mathrm{~T}_{3}$ and $\mathrm{T}_{4}$ was $6.67 \pm 0.19$, $7.05 \pm 0.06,7.13 \pm 0.09$ and $7.85 \pm 0.08$ liter/day, respectively. Overall milk production was higher in $\mathrm{T}_{4}$ Guar meal fed group as compared to $\mathrm{T}_{3}, \mathrm{~T}_{2}$ and $\mathrm{T}_{1}$ in Gir cows.
Milk is a complex mixture of fats, proteins, carbohydrates (Lactose), minerals, vitamins and other miscellaneous constituent's dispered in water. Milk yield in $\mathrm{T}_{4}$ was higher $(\mathrm{P}<0.05)$ as compared to other treatments due to affected by Guar meal. The decling trend of milk due to seasonal effect as well as stage of lactation. Milk production was higher in cows with higher DM intake reported by Chatterjee and Walli (2003), Morteza and Quazvinian (2010). Increases yield of milk on the diets supplemented with the true protein reported by Brito and Broderick (2007). Selehpour et al. (2012) found that increasing milk yield with feeding of Guar meal diet, Sirohi et al. (2013) founded that protein supplements improved milk production in cow. Soliman et al. (2014) indicated that protein supplements in animal diet will have a positive effect on milk yield. Similar result also reported by Mishra et al. (2018).

Table 5: Daily milk production (liter)/cow under different treatments during winter season

\begin{tabular}{lllll}
\hline Parameter & $\mathbf{T}_{1}$ & $\mathbf{T}_{2}$ & $\mathbf{T}_{3}$ & $\mathbf{T}_{4}$ \\
\hline Morning & $3.63^{\mathrm{d}} \pm 0.29$ & $3.85^{\mathrm{b}} \pm 0.09$ & $3.73^{\mathrm{c}} \pm 0.17$ & $4.33^{\mathrm{a}} \pm 0.15$ \\
Evening & $3.04^{\mathrm{d}} \pm 0.20$ & $3.20^{\mathrm{c}} \pm 0.07$ & $3.40^{\mathrm{b}} \pm 0.06$ & $3.52^{\mathrm{a}} \pm 0.10$ \\
Total & $6.67^{\mathrm{d}} \pm 0.19$ & $7.05^{\mathrm{c}} \pm 0.06$ & $7.13^{\mathrm{b}} \pm 0.09$ & $7.85^{\mathrm{a}} \pm 0.08$ \\
\hline
\end{tabular}

Means having different superscripts differ significantly $(\mathrm{P}<0.05)$.

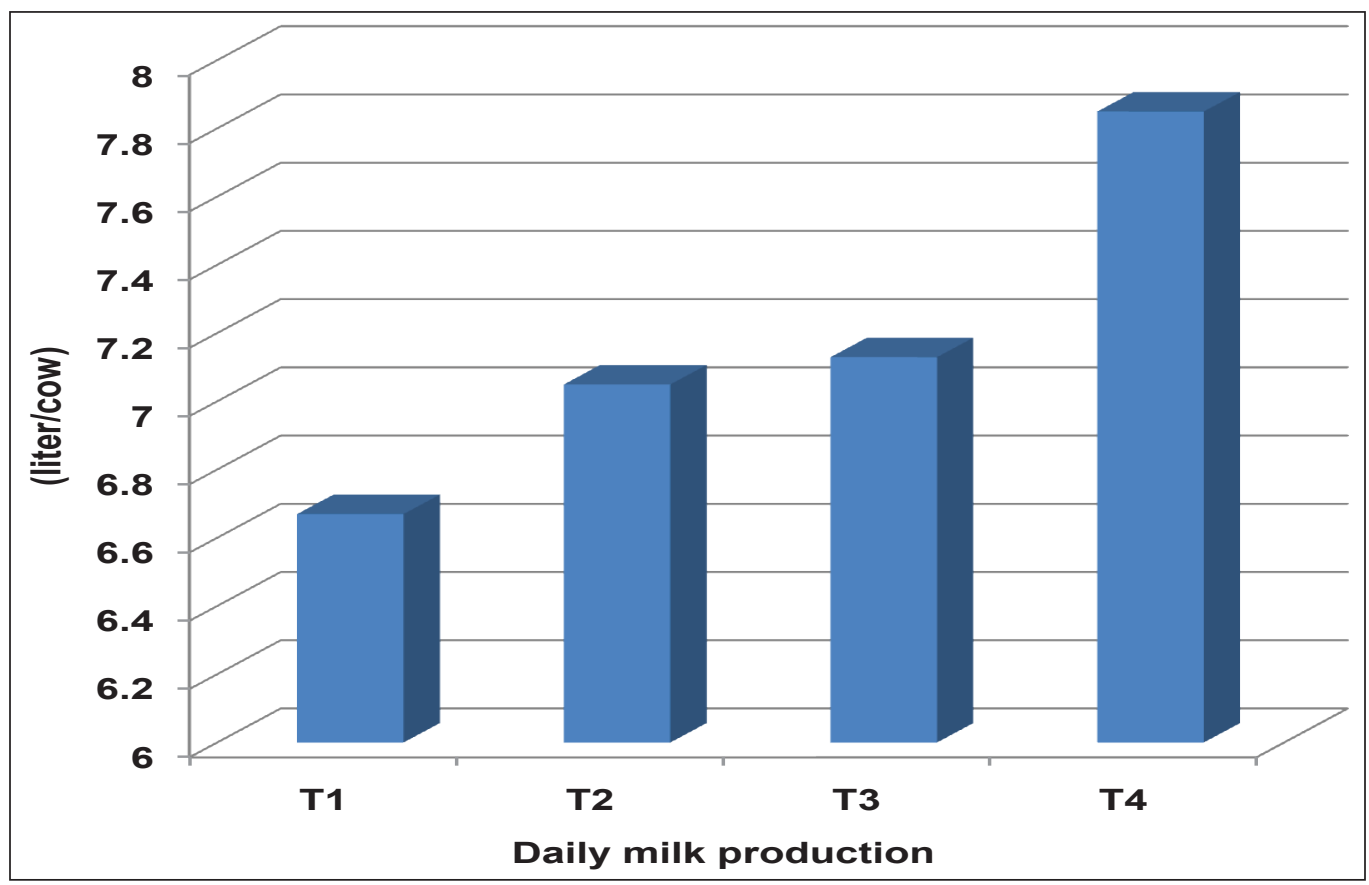

Fig. 1: Daily milk production (liter/cow) under different treatments during winter season 


\section{CONCLUSION}

Therefore, It can be concluded that feeding of Guar meal $\left(\mathrm{T}_{4}\right)$ increased the milk production and digestibility as compared to Urea and Mustard oil cake feeding in Gir cows as well as increased palatability and utility of poor quality roughage (Wheat straw). Guar meal feeding group was also more economical as well as better perform of milk production of Gir cows during winter season.

\section{ACKNOWLEDGEMENTS}

It is a great pleasure for me to express sincere and deepest sense of gratitude and indebtedness to Department of Livestock Production Management, SKNAU, Jobner for providing all the necessary facilities for conducting this experiment.

\section{REFERENCES}

Batista, E. D., Detmann, E., Gomes, D. I., Rufino, L. M. A. and Reis, W. L. S., 2016. Effect of protein supplementation in the rumen, abomasum, or both on intake, digestibility, and nitrogen utilisation in cattle fed high-quality tropical forage. J. Prod. Sci., 57(10): 1993-2000.

Broderick, G.A. 2003. Effects of Varying Dietary Protein and Energy Levels on the Production of Lactating Dairy Cows. $J$. Dairy Sci., 86(4): 1370-1381.

Brito, A.F. and Broderick, G.A. 2007. Effects of different protein supplements on milk production and nutrient utilization in lactating dairy cows. J. Dairy Sci., 90(4): 1816-1827.

Chatterjee, A. and Walli, T.K. 2003. Economics of feeding formaldehyde treated mustard cake as bypass protein to growing buffalo calves. Ind. J. dairy Sci., 56: 241-244.

Felisberto, N.R.D.O., Rodrigues, M.T., Bomfim, M.A.D.B. and Silva, M.M.C.D. 2011. Effects of different sources of protein on digestive characteristics, microbial efficiency, and nutrient flow in dairy goats. R. Bras. Zootec., 40(10): 2228-2234.

Garg, M.R., Sherasia, L.P., Bhanderi, B.M., Gulati, S.K. and Scott, T.W., 2003. Effect of feeding formaldehyde treated guar meal on milk production in crossbred cows. Ind. J. Anim. Nutri., 20(3): 334-338.

Gaur, G.K., Kaushik, S.N. and Garg, R.C. 2003. The Gir cattle breed of India - characteristics and present status PH-7, Pallavpuram Phase II, Modipuram, Meerut-250 110, Uttar Pradesh, 33: 21-29.

Government of India, 2019. Basic animal husbandry statistics. Department of animal husbandry, dairying and fisheries, Ministry of Agriculture, Govt. of India. 1: 1-9.
IGFRI, 2010. Indian Grassland and Fodder Research Institute. Jhashi.

Imaizumi, H., Santos, F.A.P., Bittar, C.M.M. and Correia, P.S., 2010. Diet crude protein content and sources for lactating dairy cattle. J. Sci. Agri., 67(1): 16-22.

Jelantik, I.G.N, Penu, C.L. and Weisberjg, M.R. 2010. Effects of Fishmeal or Urea Supplementation on Ruminal Fibre Digestion and Passage Kinetics in Bali Cows. J. Anim. Prod., 12(2): 74-81.

Jongwe, C., Thakur, S.S., Kaur, J. and Mahesh, M.S. 2014. Effect of replacing Groundnut cake with Guar (Cyamopsis tetragonoloba) meal in concentrate mixture with and without add edsweetner and flavour on production performance of Sahiwal cows. Ind. J. Anim. Nutria., 31(2): 138-142.

Khandaker, Z.H., Uddin, M.M., Sultana, M.N. and Peters, K.J. 2011. Effect of supplementation of mustard oil cake on intake, digestibility and microbial protein synthesis of cattle in a straw-based diet. Animal health production.

Mishra, R.K., Baghel, R.P.S., Mishra, C., Sharma, R. and Sharma, S. 2018. Effect of balance diet containing formaldehyde treated mustard oilseed cake on performance of lactating buffaloes. J. Ento. and Zool. Stud., 6(4): 257-261.

Morteza, S. and Qazvinian, K. 2010. Effects of Feeding Different Levels of Guar meal on Performance and Blood Metabolites in Holstein Lactating Cows. Luc. Stiintif., 55: 196-200.

Prasad, R.D., Reddy, M.R. and Reddy, G.V.N. 1998. Effect of feeding baled and stacked urea treated rice straw on the performance of crossbred cows. Anim. F. Sci. and Tech., 73(3-4): 347-352.

Rekhate, D.H., Patil, J.M. and Dhok, A.P. 2008. Nutrients utilization and grouth performance of goat. Ind. J. Anim. Nutri., 23(4): 235-236.

Rufino, L.M.A., Detmann, E., Sampaio, C.B. and Reis, W.L.S. 2016. Intake, digestibility and nitrogen utilization in cattle fed tropical forage and supplemented with protein in the rumen, abomasum, or both. J. Anim. Sci. and Biotech., 7(11): 1-10.

Sehwag, S.S. and Das, M. 2015. Present study on utilization of mustard oil and cake. Ind. J. Trad. Knowl., 14(2): 244-250.

Salehpour, M., Qazvinian, K. and Vasco, A.P.C. 2012. Effects of feeding different levels of guar meal on performance and blood metabolites in Holstein lactating cows. Scientific Papers, Anim. Sci., 54: 73-75.

Sharma, S.L., Singh, P., Patil, A.K., Verma, A.K., Chaturvedi, V.B. and Kumar, S. 2012. Effect of feeding Compressed Complete Feed Block (CCFB) containing 5 per cent Guar meal on the performance of crossbred calves. Ind. J. Anim. Nutri., 29(3): 231-234.

Sirohi, S.K., Walli, T.K., Garg, M.R. and Kumar, B.,2013. Effect of formaldehyde treated mustard cake on nutrient utilization 
and milk production performance in crossbred cows fed wheat straw based diet. Ind. J. Anim. Nutri., 30(1): 5-11.

Soliman, M.S., Okazy, A.M., Salma, H. and Hafsa, A. 2014. Effect of partially or totally replacing soybean meal by guar korma meal on sheep and cows performance milk production. $J$. Anim. Poult. Prod., 5(2): 43 -55.

Sudhakar, K., Reddy, G.V.K. and Krishna, N. 2002. Effect of Supplementation of Urea-Molasses Mineral Blocks (UMMB) on Quantity and Quality of Milk Production in Murrah Buffaloes. Ind. J. Anim. Nutri., 19(4): 301-305.
Wala, W.M.A., Sayed, S.K., Sabek, R.A.M. and Sobhy, H.M., 2016. Effect of using Guar Korma Meal as a New Source of Protein on Productive Performance of Buffalos. Asian. $J$. Anim. Sci., 10(6): 300-306.

Wanapat, M., Kang, S., Hankla, N. and Phesatcha, K. 2013. Effect of rice straw treatment on feed intake and milk production in lactating dairy cows. Afri. J. Agri. Res., 8(17): 1677-1687. 
